\title{
円形ターゲットの中心位置の計測手法の比較
}

\section{Comparison of Measuring Methods of Circular Target Location}

\author{
松岡 龍治 $*, * *$ 曽根 光男*・須藤 昇*・横塚 英世*・白井 直樹** \\ Ryuji MATSUOKA, Mitsuo SONE, Noboru SUDO, \\ Hideyo YOKOTSUKA and Naoki SHIRAI
}

\begin{abstract}
A circular target on a plane is projected as an ellipse onto an oblique image. This paper reports an experiment conducted to evaluate measuring methods of elliptical target location by using simulated images of various sizes, eccentricities, and rotation angles of elliptical targets. Three popular measuring methods in digital photogrammetry: unweighted centroid method using a binary image created by thresholding (BCM), weighted centroid method (WCM), and least squares matching (LSM) were investigated. The experiment results show that $\mathrm{BCM}$ is robust against flatness and rotation of a target, and image noise. However, BCM cannot produce more accurate measuring results than WCM and LSM. Meanwhile, the results demonstrate that WCM is robust against flatness and rotation of a target, and WCM can achieve the most accurate measurement when a target image has no image noise. However, the measuring error of WCM would be proportional to the magnitude of image noises, and WCM would be unable to provide the best measuring results when a target image has larger image noises. The results indicate that LSM is rather robust against image noise, but very sensitive to flatness and rotation of a target. Moreover, the results show that BCM using an enlarged target image by bi-linear interpolation should be a good measuring method on accuracy and robustness against flatness and rotation of a target, and image noise.
\end{abstract}

\section{1.はじめに}

非計測用カメラを対象としたカメラキャリブレー ションでは, 2 次元平面上に分布する標定点を用いる 方法がよく用いられている。現在市販されている非計 測用カメラに対応した画像計測ソフトウェアのカメラ キャリブレーションに扔いても，2 次元平面上に分布 する標定点を撮影した画像（アナログ写真をディジ夕 ル化した画像も含めて）を用いる方法を採用している ものがある（EOS Systems Inc., 2003, クラボウ エ レクトロニクス事業部, 2001)。このようなカメラキャ リブレーションでは, 標定点として円形ターゲットを 採用し, 撮影画像上でのその中心位置をディジタル画

* 東海大学情報技術センター

Tokai University Research \& Information Center **国際航業株式会社

Kokusai Kogyo Co., Ltd.

「写真測量とリモートセンシング」VOL. 48，NO. 3，2009
像処理技術により自動計測することが一般的となって いる。また, カメラキャリブレーションに限らず, 対象 物の 3 次元計測に打いても, ディジ夕ル画像処理技術 を利用して撮影画像上での円形ターゲットの中心位置 を自動計測することが行われている(服部ほか, 2001)。

ディジタル画像処理技術を利用して撮影画像上の円 形ターゲットの中心位置を計測する手法としては, 撮 影画像を 2 值化することによって図形を抽出した後, その 2 值図形の重心を求める方法（近津ほか, 2001）, 濃淡レベルから計算される重みを用いた加重平均によ り濃淡図形の重心を求妨法(服部ほか, 1999), 最 小 2 乗マッチング法（EOS Systems Inc., 2003）など がある。

本論文は，これらの計測手法の計測精度を比較する ため, 様及な大きさの円形ターゲットのシミュレー ション画像を用いて行った実験の結果を報告するもの である。

一般に円形ターゲットは撮影画像では楕円となり， 円形ターゲットの中心を画像へ投影した位置が円形 
ターゲットの撮影画像上での本来の位置であるが，こ の位置と撮影画像上での楕円の中心位置との間には, 鉛直撮影以外ではずれが生じる。このずれは円形夕ー ゲットの画像上の位置として楕円の中心を採用した場 合に発生する誤差であり，本論文では，この誤差を偏 心誤差と呼ぶことにする。偏心誤差に対し，ディジ夕 儿画像処理技術を利用して撮影画像上の楕円の中心位 置を計測する際の誤差を単に計測誤差と呼ぶことにす る。

本論文では, まず偏心誤差について簡単に述べた後, 計測誤差に関する実験について報告する。

\section{2. 偏心誤差}

\section{1 偏心誤差の一般式}

対象物空間座標系を $(X, Y, Z)$, 画像座標系を $(x$, y) とし, 画面距離が $c$ であるカメラを用いて画像を撮 影するときのカメラの位置を $\left(X_{0}, Y_{0}, Z_{0}\right)$, 姿勢を $(\omega$, $\phi, \varkappa)$ とする。

点 $\mathrm{P}_{\mathrm{c}}\left(X_{\mathrm{c}}, Y_{\mathrm{c}}, Z_{\mathrm{c}}\right)$ を中心とする水平面 $Z=Z_{\mathrm{c}}$ 上の 半径 $R$ の円を撮影したとき, 円の中心 $\mathrm{P}_{\mathrm{C}}$ が画像に撮 影される点 $\mathrm{p}_{\mathrm{c}}\left(x_{\mathrm{c}}, y_{\mathrm{c}}\right)$ の画像上の位置は, 次式(1)で表 される。

$\left\{\begin{array}{l}x_{\mathrm{C}}=-c \frac{a_{11}\left(X_{\mathrm{C}}-X_{0}\right)+a_{12}\left(Y_{\mathrm{C}}-Y_{0}\right)+a_{13}\left(Z_{\mathrm{C}}-Z_{0}\right)}{a_{31}\left(X_{\mathrm{C}}-X_{0}\right)+a_{32}\left(Y_{\mathrm{C}}-Y_{0}\right)+a_{33}\left(Z_{\mathrm{C}}-Z_{0}\right)} \\ y_{\mathrm{C}}=-c \frac{a_{21}\left(X_{\mathrm{C}}-X_{0}\right)+a_{22}\left(Y_{\mathrm{C}}-Y_{0}\right)+a_{23}\left(Z_{\mathrm{C}}-Z_{0}\right)}{a_{31}\left(X_{\mathrm{C}}-X_{0}\right)+a_{32}\left(Y_{\mathrm{C}}-Y_{0}\right)+a_{33}\left(Z_{\mathrm{C}}-Z_{0}\right)}\end{array}\right.$

ただし， $a_{11} \sim a_{33}$ は以下のと抒である。

$\left[\begin{array}{lll}a_{11} & a_{12} & a_{13} \\ a_{21} & a_{22} & a_{23} \\ a_{31} & a_{32} & a_{33}\end{array}\right]=\left[\begin{array}{ccc}1 & 0 & 0 \\ 0 & \cos \omega & -\sin \omega \\ 0 & \sin \omega & \cos \omega\end{array}\right]\left[\begin{array}{ccc}\cos \phi & 0 & \sin \phi \\ 0 & 1 & 0 \\ -\sin \phi & 0 & \cos \phi\end{array}\right]\left[\begin{array}{ccc}\cos x & -\sin \psi & 0 \\ \sin \psi & \cos x & 0 \\ 0 & 0 & 1\end{array}\right]$

一方, $\mathrm{P}_{\mathrm{c}}\left(X_{\mathrm{c}}, Y_{\mathrm{c}}, Z_{\mathrm{c}}\right)$ を中心とする水平面 $Z=Z_{\mathrm{c}}$ 上 の半径 $R$ の円は, 撮影画像上では楕円となり, その中 心 $\mathrm{p}_{\mathrm{E}}\left(x_{\mathrm{E}}, y_{\mathrm{E}}\right)$, 長半径 $a$, 短半径 $b$, 長軸の回転角 $\alpha$ は, 以下の式(3) (5)で求められる。

$\left\{\begin{array}{l}x_{\mathrm{E}}=-c \frac{B E-D F}{A B-D^{2}} \\ y_{\mathrm{E}}=-c \frac{A F-D E}{A B-D^{2}}\end{array}\right.$

$\left\{\begin{array}{l}a=\max (s, t) \\ b=\min (s, t)\end{array}\right.$ $\alpha=\frac{1}{2} \tan ^{-1} \frac{2 D}{A-B}$

ただし，A〜F， $s ， t$ は以下のと扔りである。

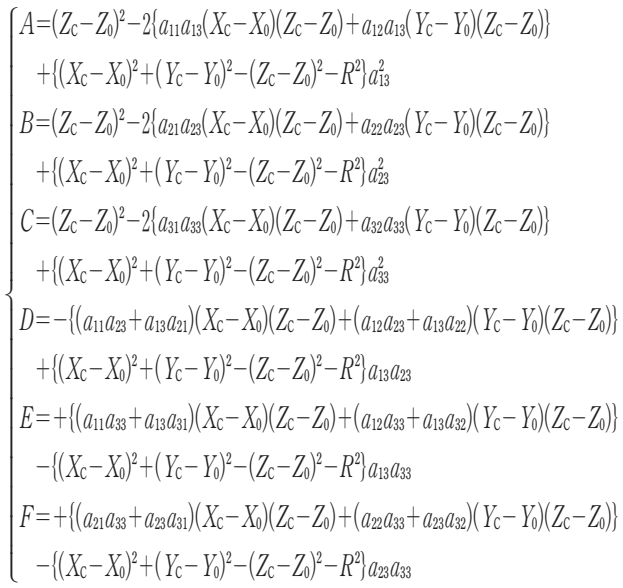

$\left\{\begin{array}{l}s=\sqrt{-\frac{2\left(A x_{\mathrm{E}}^{2}+B y_{\mathrm{E}}^{2}+C f^{2}+2 D x_{\mathrm{E}} y_{\mathrm{E}}+2 E x_{\mathrm{E}} f+2 F y_{\mathrm{E}} f\right)}{(A+B)+\sqrt{(A-B)^{2}+4 D^{2}}}} \\ t=\sqrt{-\frac{2\left(A x_{\mathrm{E}}^{2}+B y_{\mathrm{E}}^{2}+C f^{2}+2 D x_{\mathrm{E}} y_{\mathrm{E}}+2 E x_{\mathrm{E}} f+2 F y_{\mathrm{E}} f\right)}{(A+B)-\sqrt{(A-B)^{2}+4 D^{2}}}}\end{array}\right.$

よって, 円の中心 $\mathrm{P}_{\mathrm{C}}$ が画像に撮影される点 $\mathrm{p}_{\mathrm{c}}\left(x_{\mathrm{C}}\right.$, $\left.y_{\mathrm{C}}\right)$ と撮影画像上での楕円の中心 $\mathrm{p}_{\mathrm{E}}\left(x_{\mathrm{E}}, y_{\mathrm{E}}\right)$ との位置 のずれである偏心誤差 $\Delta \mathrm{p}(\Delta x, \Delta y)$ は次式(8)で求めら れる。

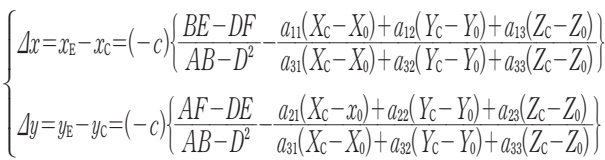

以上のように, 偏心誤差 $\Delta \mathrm{p}(\Delta x, \Delta y)$ は, カメラの画 面距離 $c$, 画像撮影時のカメラの位置 $\left(X_{0}, Y_{0}, Z_{0}\right)$ と姿 勢 $(\omega, \phi, x)$, および対象となる円形夕ーゲットの中心 位置 $\left(X_{\mathrm{C}}, Y_{\mathrm{C}}, Z_{\mathrm{c}}\right)$ とその半径 $R$ によって求められる ことになる。

\section{2 偏心誤差の試算}

EOS Systems Inc. 製の PhotoModeler Pro 5 での カメラキャリブレーションを参考にして, 楕円の形状 (長半径 $a$, 短半径 $b$, 長軸の回転角 $\alpha$ ) 扔よび偏心誤 差 $\Delta \mathrm{p}(\Delta x, \Delta y)$ を試算した。

PhotoModeler Pro 5 でのカメラキャリブレーショ ンは, 図 1 (a)に示すような縦10個 $\times$ 横10個の合計100個 の円形ターゲットが描かれている Calibration Grid を斜めに撮影した画像を用いる（EOS Systems Inc., 


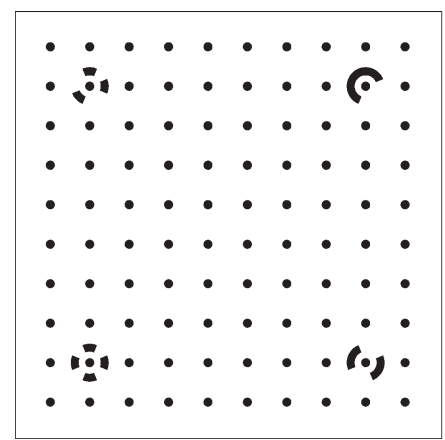

(a) Calibration Grid

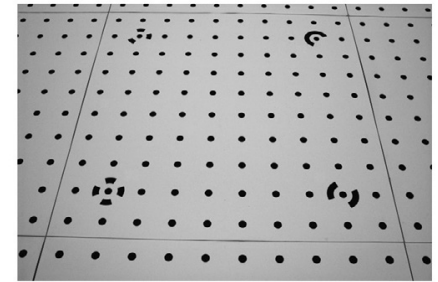

(b) 撮影画像

図 1 PhotoModeler Pro 5 の Calibration Grid とその撮影画像

2003)。この Calibration Grid では, 円形ターゲットの 中心間の距離を 1 とすると, 円形ターゲットの半径は 0.1125 となっている。図1(b)に,この Calibration Grid を撮影した画像の例を示す。

楕円の形状および偏心誤差の試算は以下の条件で 行った。

(1) 円形ターゲットの半径 $R$ を $11.25 \mathrm{~mm}$ とする。

(2) 撮影に用いるカメラは $35 \mathrm{~mm}$ 判カメラ（画面サイ ズ： $36 \mathrm{~mm} \times 24 \mathrm{~mm}$ ) とし，図 2 に示すように，画面 の横置き(横位置) と縦置き(縦位置) の 2 種類の 撮影を行う。

(3) カメラの画面距離 $c$ は $24 \mathrm{~mm}, 35 \mathrm{~mm}, 50 \mathrm{~mm}$ の 3 種類とする。

(4) 撮影は，奥行き方向の撮影距離 $\left(Z_{\mathrm{C}}-Z_{0}\right)$ を 1,000 $\mathrm{mm}$ とし, 鉛直撮影からの撮影方向の傾き(撮影角) $\theta$ は $15^{\circ}, 30^{\circ}, 45^{\circ} の 3$ 種類とする。なお, 画像撮影時 のカメラの姿勢が $(\omega, \phi, x)=(-\theta, 0,0)$ を満足する ように対象物空間座標系 $(X, Y, Z)$ を設定する。

(5) $c=35 \mathrm{~mm}, \theta=30^{\circ}$ のきの撮影を標準撮影と考 え, 表 1 に示すように, $(c, \theta)$ の組み合わせとして, 標準撮影の $\left(35 \mathrm{~mm}, 30^{\circ}\right)$ 以外に，(24mm, 30 $)$ ，(50 $\left.\mathrm{mm}, 30^{\circ}\right),\left(35 \mathrm{~mm}, 15^{\circ}\right),\left(35 \mathrm{~mm}, 45^{\circ}\right)$ の 4 種類, 合わ せて 5 種類の撮影を行う。

（6）楕円の形状および偏心誤差の試算は, 図 2 におい て, 横一上, 横一下, 縦一上, 縦一下と示した位置 で行う。この 4 箇所は, 横位置および縦位置のとき, 画面枠から長辺㧍よび短辺の長さの $10 \%$ の距離だけ 内側となる位置である。

以上の条件で試算を行った結果を表 1 に示す。この 表 1 において, $r=\sqrt{a b}$ は, 長半径 $a$, 短半径 $b$ の楕円 と面積が等しい円（以後，等積円と呼ぶことにする）

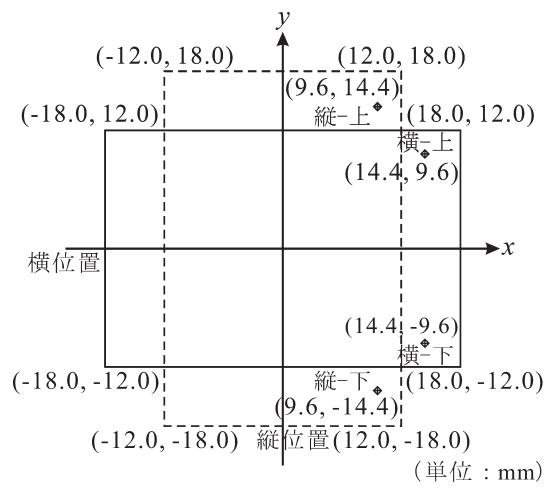

図 2 画像座標系における $35 \mathrm{~mm}$ 判カメラの画面

の半径であり, $\Delta s$ は, 偏心誤差 $(\Delta x, \Delta y)$ の大きさ $\sqrt{(\Delta x)^{2}+(\Delta y)^{2}}$ である。表 1 には参考として $\Delta s / r$ の值

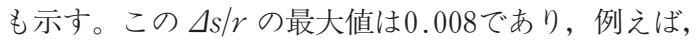
撮影画像上で $r$ が $5 ， 10 ， 20 ， 40$ 画素の円では， $\Delta s$ が それぞれ $0.04 ， 0.08 ， 0.16 ， 0.32$ 画素となることを意 味している。この偏心誤差の值は, 本論文に示す実験 で得られた計測誤差に比べて無視できない大きさであ るため, 今回設定したような撮影条件では, 偏心誤差 を補正する必要があることになる。

考えられる偏心誤差の補正方法を, 標定を例として 述べることにする。ここで, カメラの画面距離 $c$ と円 形ターゲットの半径 $R$ は既知とする。また， 2 枚以上 の画像に撮影されていない円形ターゲットについて は, その $Z$ 座標 $Z_{\mathrm{c}}$ 既知とする。偏心誤差の補正は以 下の手順で行われる。

(i) 計測された楕円の中心の画像座標 $\left(x_{\mathrm{E}}, y_{\mathrm{E}}\right)$ を円形 ターゲットの画像座標 $\left(x_{\mathrm{c}}, y_{\mathrm{C}}\right)$ として, 画像撮影時 のカメラの位置 $\left(X_{0}, Y_{0}, Z_{0}\right)$ と姿勢 $(\omega, \phi, \chi)$ を求め る。 
表 1 投影棈円の形状と偏心誤差の大きさ

\begin{tabular}{|c|c|c|c|c|c|c|c|}
\hline & & & (a) & (b) & (c) & (d) & (e) \\
\hline \multicolumn{3}{|c|}{ 画面距離 C } & $35 \mathrm{~mm}$ & $24 \mathrm{~mm}$ & $50 \mathrm{~mm}$ & $35 \mathrm{~mm}$ & $35 \mathrm{~mm}$ \\
\hline \multicolumn{3}{|c|}{ 撮影角 $\theta$} & $30^{\circ}$ & $30^{\circ}$ & $30^{\circ}$ & $15^{\circ}$ & $45^{\circ}$ \\
\hline \multicolumn{3}{|c|}{ 長半径 $a$} & $0.299 \mathrm{~mm}$ & $0.193 \mathrm{~mm}$ & $0.443 \mathrm{~mm}$ & $0.361 \mathrm{~mm}$ & $0.213 \mathrm{~mm}$ \\
\hline \multicolumn{3}{|c|}{ 短半径 $b$} & $0.201 \mathrm{~mm}$ & $0.112 \mathrm{~mm}$ & $0.326 \mathrm{~mm}$ & $0.308 \mathrm{~mm}$ & $0.098 \mathrm{~mm}$ \\
\hline \multicolumn{3}{|c|}{$r=\sqrt{a b}$} & $0.245 \mathrm{~mm}$ & $0.147 \mathrm{~mm}$ & $0.380 \mathrm{~mm}$ & $0.333 \mathrm{~mm}$ & $0.145 \mathrm{~mm}$ \\
\hline \multirow{6}{*}{ 横一上 } & \multicolumn{2}{|c|}{ 扁平率 $f$} & 0.327 & 0.419 & 0.265 & 0.146 & 0.538 \\
\hline & \multicolumn{2}{|c|}{ 回転角 $\alpha$} & $-15.2^{\circ}$ & $-15.9^{\circ}$ & $-13.7^{\circ}$ & $-21.1^{\circ}$ & $-10.0^{\circ}$ \\
\hline & \multirow{4}{*}{$\begin{array}{l}\text { 偏心 } \\
\text { 誤差 }\end{array}$} & $\Delta x$ & $0.0002 \mathrm{~mm}$ & $0.0002 \mathrm{~mm}$ & $0.0003 \mathrm{~mm}$ & $0.0001 \mathrm{~mm}$ & $0.0002 \mathrm{~mm}$ \\
\hline & & $\Delta y$ & $-0.0009 \mathrm{~mm}$ & $-0.0004 \mathrm{~mm}$ & $-0.0014 \mathrm{~mm}$ & $-0.0008 \mathrm{~mm}$ & $-0.0004 \mathrm{~mm}$ \\
\hline & & $\Delta s$ & $0.0009 \mathrm{~mm}$ & $0.0005 \mathrm{~mm}$ & $0.0015 \mathrm{~mm}$ & $0.0008 \mathrm{~mm}$ & $0.0005 \mathrm{~mm}$ \\
\hline & & $\Delta s / r$ & 0.0036 & 0.0034 & 0.0039 & 0.0025 & 0.0034 \\
\hline \multirow{9}{*}{ 横－下 } & \multicolumn{2}{|c|}{ 長半径 $a$} & $0.438 \mathrm{~mm}$ & $0.345 \mathrm{~mm}$ & $0.573 \mathrm{~mm}$ & $0.439 \mathrm{~mm}$ & $0.396 \mathrm{~mm}$ \\
\hline & \multicolumn{2}{|c|}{ 短半径 $b$} & $0.357 \mathrm{~mm}$ & $0.256 \mathrm{~mm}$ & $0.492 \mathrm{~mm}$ & $0.393 \mathrm{~mm}$ & $0.287 \mathrm{~mm}$ \\
\hline & \multicolumn{2}{|c|}{$r=\sqrt{a b}$} & $0.396 \mathrm{~mm}$ & $0.297 \mathrm{~mm}$ & $0.531 \mathrm{~mm}$ & $0.416 \mathrm{~mm}$ & $0.337 \mathrm{~mm}$ \\
\hline & \multicolumn{2}{|c|}{ 扁平率 $f$} & 0.185 & 0.257 & 0.141 & 0.105 & 0.276 \\
\hline & \multicolumn{2}{|c|}{ 回転角 $\alpha$} & $-42.5^{\circ}$ & $-47.1^{\circ}$ & $-35.5^{\circ}$ & $-53.1^{\circ}$ & $-31.3^{\circ}$ \\
\hline & \multirow{4}{*}{$\begin{array}{l}\text { 偏心 } \\
\text { 誤差 }\end{array}$} & $\Delta x$ & $0.0005 \mathrm{~mm}$ & $0.0005 \mathrm{~mm}$ & $0.0004 \mathrm{~mm}$ & $0.0001 \mathrm{~mm}$ & $0.0007 \mathrm{~mm}$ \\
\hline & & $\Delta y$ & $-0.0022 \mathrm{~mm}$ & $-0.0018 \mathrm{~mm}$ & $-0.0028 \mathrm{~mm}$ & $-0.0013 \mathrm{~mm}$ & $-0.0023 \mathrm{~mm}$ \\
\hline & & $\Delta s$ & $0.0023 \mathrm{~mm}$ & $0.0019 \mathrm{~mm}$ & $0.0028 \mathrm{~mm}$ & $0.0013 \mathrm{~mm}$ & $0.0024 \mathrm{~mm}$ \\
\hline & & $\Delta s / r$ & 0.0058 & 0.0064 & 0.0054 & 0.0031 & 0.0071 \\
\hline \multirow{9}{*}{ 縦一上 } & \multicolumn{2}{|c|}{ 長半径 $a$} & $0.264 \mathrm{~mm}$ & $0.157 \mathrm{~mm}$ & $0.410 \mathrm{~mm}$ & $0.341 \mathrm{~mm}$ & $0.168 \mathrm{~mm}$ \\
\hline & \multicolumn{2}{|c|}{ 短半径 $b$} & $0.169 \mathrm{~mm}$ & $0.084 \mathrm{~mm}$ & $0.291 \mathrm{~mm}$ & $0.288 \mathrm{~mm}$ & $0.067 \mathrm{~mm}$ \\
\hline & \multicolumn{2}{|c|}{$r=\sqrt{a b}$} & $0.211 \mathrm{~mm}$ & $0.115 \mathrm{~mm}$ & $0.345 \mathrm{~mm}$ & $0.314 \mathrm{~mm}$ & $0.106 \mathrm{~mm}$ \\
\hline & \multicolumn{2}{|c|}{ 扁平率 $f$} & 0.361 & 0.465 & 0.291 & 0.156 & 0.602 \\
\hline & \multicolumn{2}{|c|}{ 回転角 $\alpha$} & $-8.6^{\circ}$ & $-8.7^{\circ}$ & $-7.9^{\circ}$ & $-12.3^{\circ}$ & $-5.3^{\circ}$ \\
\hline & & $\Delta x$ & $0.0001 \mathrm{~mm}$ & $0.0001 \mathrm{~mm}$ & $0.0002 \mathrm{~mm}$ & $0.0001 \mathrm{~mm}$ & $0.0001 \mathrm{~mm}$ \\
\hline & 偏心 & $\Delta y$ & $-0.0006 \mathrm{~mm}$ & $-0.0003 \mathrm{~mm}$ & $-0.0012 \mathrm{~mm}$ & $-0.0007 \mathrm{~mm}$ & $-0.0002 \mathrm{~mm}$ \\
\hline & 詔差 & $\Delta s$ & $0.0007 \mathrm{~mm}$ & $0.0003 \mathrm{~mm}$ & $0.0012 \mathrm{~mm}$ & $0.0007 \mathrm{~mm}$ & $0.0002 \mathrm{~mm}$ \\
\hline & & $\Delta s / r$ & 0.0031 & 0.0025 & 0.0035 & 0.0023 & 0.0024 \\
\hline \multirow{9}{*}{ 縦一下 } & \multicolumn{2}{|c|}{ 長半径 $a$} & $0.471 \mathrm{~mm}$ & $0.383 \mathrm{~mm}$ & $0.599 \mathrm{~mm}$ & $0.459 \mathrm{~mm}$ & $0.433 \mathrm{~mm}$ \\
\hline & \multicolumn{2}{|c|}{ 短半径 $b$} & $0.405 \mathrm{~mm}$ & $0.302 \mathrm{~mm}$ & $0.544 \mathrm{~mm}$ & $0.416 \mathrm{~mm}$ & $0.356 \mathrm{~mm}$ \\
\hline & \multicolumn{2}{|c|}{$r=\sqrt{a b}$} & $0.437 \mathrm{~mm}$ & $0.340 \mathrm{~mm}$ & $0.571 \mathrm{~mm}$ & $0.437 \mathrm{~mm}$ & $0.393 \mathrm{~mm}$ \\
\hline & 扁于 & 六 $f$ & 0.139 & 0.213 & 0.092 & 0.093 & 0.176 \\
\hline & 回車 & 百 $\alpha$ & $-56.9^{\circ}$ & $-62.2^{\circ}$ & $-46.6^{\circ}$ & $-66.8^{\circ}$ & $-41.9^{\circ}$ \\
\hline & & $\Delta x$ & $0.0003 \mathrm{~mm}$ & $0.0004 \mathrm{~mm}$ & $0.0003 \mathrm{~mm}$ & $0.0001 \mathrm{~mm}$ & $0.0006 \mathrm{~mm}$ \\
\hline & 偏心 & $\Delta y$ & $-0.0027 \mathrm{~mm}$ & $-0.0024 \mathrm{~mm}$ & $-0.0033 \mathrm{~mm}$ & $-0.0014 \mathrm{~mm}$ & $-0.0031 \mathrm{~mm}$ \\
\hline & 誤差 & $\Delta s$ & $0.0027 \mathrm{~mm}$ & $0.0024 \mathrm{~mm}$ & $0.0033 \mathrm{~mm}$ & $0.0014 \mathrm{~mm}$ & $0.0032 \mathrm{~mm}$ \\
\hline & & $\Delta s / r$ & 0.0063 & 0.0072 & 0.0057 & 0.0032 & 0.0081 \\
\hline
\end{tabular}


(ii) 求められたカメラの位置 $\left(X_{0}, Y_{0}, Z_{0}\right)$ と姿勢 $(\omega$, $\phi, x)$ を用いて，円形ターゲットの対象物空間座標 $\left(X_{\mathrm{C}}, Y_{\mathrm{C}}, Z_{\mathrm{C}}\right)$ を求める。

(iii) 求められた対象物空間座標 $\left(X_{\mathrm{C}}, Y_{\mathrm{C}}, Z_{\mathrm{C}}\right)$ を用い て，式(8)より偏心䛊差 $(\Delta x, \Delta y)$ を求める。

(iv) 求められた偏心誤差 $(\Delta x, \Delta y)$ を用いて, $\left(x_{\mathrm{E}}-\Delta x\right.$, $\left.y_{\mathrm{E}}-\Delta y\right)$ を計算し，己れを円形ターゲットの補正さ れた画像座標として用いて，あらためてカメラの位 置 $\left(X_{0}, Y_{0}, Z_{0}\right)$ と姿勢 $(\omega, \phi, x)$ を求める。

(v) 以降, (iii)で計算される偏心誤差 $(\Delta x, \Delta y)$ の変化量 が設定したしきい值以下となるまで，あるいは，(iv) で求められるカメラの位置 $\left(X_{0}, Y_{0}, Z_{0}\right)$ と姿勢 $(\omega$, $\phi, x)$ の変化量が設定したしきい值以下となるまで, (ii) ( (iv)の処理を繰り返す。

以上が標定における偏心誤差の補正方法として考え られる方法である。3 次元計測の場合は，(i)と(iv)にお いて画像撮影時の位置 $\left(X_{0}, Y_{0}, Z_{0}\right)$ と姿勢 $(\omega, \phi, \chi)$ を 求女る処理を行わず, (v)における処理の終了判定は偏 心誤差 $(\Delta x, \Delta y)$ の変化量だけとする。

また, カメラから円形ターゲットまでの距離に比べ て，円形ターゲットの大きさが小さいときは， $\Delta x, \Delta y$ はほぼ $R^{2}$ に比例する。また $a, b$ は $R$ に比例するた め, $\Delta s / r$ がほぼ $R$ に比例することになる。つまり，小 さなターゲットを用いることにより， $\Delta s / r$ を偏心誤差 の補正が不要な程度まで小さくすることは可能であ る。ただし，撮影画像上の楕円が小さくなるため，以 下に示す実験結果から明らかなように，計測誤差は大 きくなる。

\section{3 . 画像上の楕円の中心位置の計測手法}

本論文では, 白い背景の上に描かれた黒い円形夕一 ゲットを撮影した画像において，撮影された円形夕一 ゲット（撮影画像上では楕円となる）の中心位置を計 測することを対象とする。ここで, 撮影画像の画素 $(x$, $y)$ における濃淡レベルを $P(x, y)$, 黒い楕円の濃淡レ ベルを $P_{\mathrm{F}}$, 白い背景の濃淡レベルを $P_{\mathrm{B}}$ とする。ただ し, $P_{\mathrm{F}}<P_{\mathrm{B}}$ であるとする。また, 撮影画像上での楕円 の中心位置を $\left(x_{\mathrm{E}}, y_{\mathrm{E}}\right)$ とする。

このようなディジタル画像上での棈円の中心位置を 計測する手法としては, 眓形の重心を求める方法, テ ンプレートマッチングによる方法, 困形の輪郭抽出結 果を利用する方法などがある。

\section{1 図形の重心を求める方法}

ディジタル画像上の楕円の中心位置を計測するため に用いられる, 困形の重心を求める代表的な方法とし ては，2 值化によって図形を抽出した後, その 2 值困 形の重心を求める方法と, 濃淡レベルから計算される 重みを用いた加重平均により濃淡図形の重心を求女る 方法がある。本論文では, 前者を 2 值化法, 後者を加 重平均法と呼ぶことにする。

なお，以下では，重心位置を計算する領域を制限す るため, 図形の存在が想定される領域では $M(x, y)=$ 1 , その領域外では $M(x, y)=0$ となるマスク画像 $M(x, y)$ を与えることにする。

2 值化法, 加重平均法ともに, 以下の式(9)で楕円の 中心位置 $\left(x_{\mathrm{E}}, y_{\mathrm{E}}\right)$ を求めることができる。

$\left\{\begin{aligned} x_{\mathrm{E}} & =\frac{\sum_{x} \sum_{y} M(x, y) \cdot W(x, y) \cdot x}{\sum_{x} \sum_{y} M(x, y) \cdot W(x, y)} \\ y_{\mathrm{E}} & =\frac{\sum_{x} \sum_{y} M(x, y) \cdot W(x, y) \cdot y}{\sum_{x} \sum_{y} M(x, y) \cdot W(x, y)}\end{aligned}\right.$

2 值化法と加重平均法の違いは, 式(9)における $W(x, y)$ の乞え方の違いである。

\subsubsection{2 值化法}

2 值化法では, 式(9)における $W(x, y)$ を以下の式(10) で与える。

$W(x, y)= \begin{cases}1, & P(x, y) \leq P_{\mathrm{T}} \\ 0, & P(x, y)>P_{\mathrm{T}}\end{cases}$

ここで， $P_{\mathrm{T}}$ は 2 值化のしきい值であり, $W(x, y)=$ 1 である画素は図形であり, $W(x, y)=0$ である画素は 背景とされる。

\subsection{2 加重平均法}

加重平均法では, 式(9)における $W(x, y)$ を以下の式 (11)で与える。

$W(x, y)= \begin{cases}\left(P_{\mathrm{L}}-P(x, y)\right), & P(x, y) \leq P_{\mathrm{L}} \\ 0, & P(x, y)>P_{\mathrm{L}}\end{cases}$

ここで， $P_{\mathrm{L}}$ はしきい值であり， $P(x, y) \leq P_{\mathrm{L}}$ である 画素についてのみ, 眓形の重心位置の計算に用いるこ とになる。 $P_{\mathrm{L}}=P_{\mathrm{B}}$ とするのが一般的である。 


\section{2 テンプレートマッチングによる方法}

テンプレートマッチングによって楕円の中心位置を 計測することも行われているが，その際には，図形の 変形に対応し，またサブピクセル単位で対応位置を求 めることが望ましいため, 最小 2 乗マッチング法 (LSM) が用いられることが多い。たとえば, PhotoModeler Pro 5 のカメラキャリブレーションで は，キャリブレーションシート上の楕円の中心位置の 計測は最小 2 乗マッチング法によって行うことが標準 となっている (EOS Systems Inc., 2003)。

\section{3 図形の輪郭抽出結果を利用する方法}

2 值化して図形を抽出し, その抽出図形の輪郭線を 追跡し, 輪郭線を構成する画素列より, 楕円の中心を 求める方法で，各種のアルゴリズムが提案されている (坂上·高木, 1983, Luhmann, 1986, Zhou, 1986)。 しかし，これらのアルゴリズムは一般に複雑であり， 撮影画像上での楕円の中心位置の計測で，これらの方 法が利用されることは多くないため, 本論文では, 計 測精度の比較対象としては採用しなかった。

ただし，以下に示すような簡便な方法で，楕円の方 程式を求め, その結果を最小 2 乗マッチング法のテン プレート画像を作成するときに用いた。

(i) 2 值化により図形を抽出する。

(ii) 抽出図形を構成する画素の中で，ある $x$ 座標にお いて $y$ 座標が最小あるいは最大になる画素を輪郭 画素として抽出する。同様に，ある $y$ 座標において $x$ 座標が最小あるいは最大になる画素も輪郭画素と して抽出する。

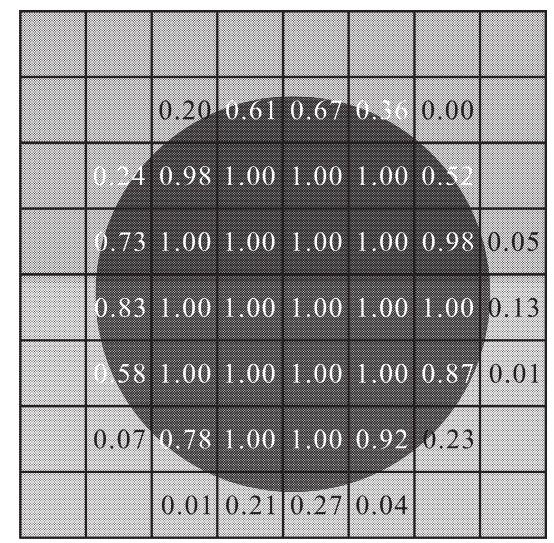

(a) 画素ごとの円形ターゲットの面積 (iii) 抽出された輪郭画素は楕円の周上にあると考之， 最小 2 乗法により楕円の方程式を求める。 なお，このような簡便な方法で求められた楕円の方 程式から計算される中心位置は, 以下に示す実験では, ほとんどの場合において $3.1 .1 て ゙$ 述べた 2 值化法で求 められる中心位置より誤差が大きかった。

\section{4. 計測精度比較実験の概要}

\section{1 実験対象画像}

今回の実験で用いた画像は, 濃淡レベルが $P_{\mathrm{B}}$ であ る背景に, 濃淡レベルが $P_{\mathrm{F}}$ である, 長半径が $a$, 短半 径が $b$, 長軸の回転角が $\alpha$ である楕円が描かれた状況 を想定し，これをディジタル画像化したものである。 画素 $i$ に含まれる円形ターゲットの面積を $A_{i}$ とする と, この画素の濃淡レベル $P_{i}$ を以下の式(12)で計算し た。

$P_{i}=A_{i} P_{\mathrm{F}}+\left(1-A_{i}\right) P_{\mathrm{B}}+\delta_{i}$

ここで， $\delta_{i}$ は現実に撮像された画像には雑音が含ま れることを考慮して加えたガウス雑音である。実験で は，その標準偏差 $\sigma_{\mathrm{N}}$ として，0，1，2，3，4，5， $6 ， 7 ， 8$ の 9 種類の值を考えた。また，円形夕ーゲッ 卜画像は 8 ビット (256レベル) のグレースケール画像 とし，がウス雑音が加わることを考慮して， $P_{\mathrm{B}}=192$, $P_{\mathrm{F}}=64$ とした。

このようにして半径が 3 画素である円をディジタル 画像化した例を図 3 に示す。図 3 の例では $\sigma_{\mathrm{N}}=0$ であ る。同図(a)に円形ターゲットが含まれる画素について

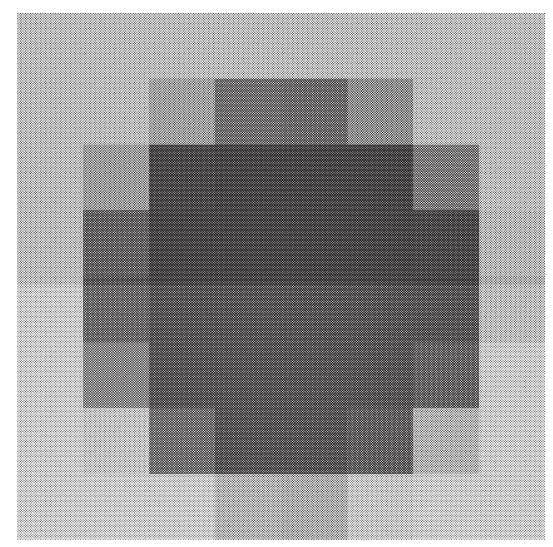

(b) 円形ターゲット画像

図 3 円形ターゲットのディジタル画像化 
その面積 $A_{i}$ を示し，この面積に従ってディジタル画 像化されたものが同図(b)である。

今回の実験で準備した楕円の大きさは, Photo Modeler Pro 5 でのカメラキャリブレーションにおい て撮影される画像上での円形ターゲットの大きさか ら，等積円の半径 $r て ゙ 2 〜 40$ 画素とした。

\section{2 中心位置の計測手法}

今回の実験では, 以下の 4 種類の計測手法で楕円の 中心位置を計測し，その結果を比較した。なお，実験 では，等積円の半径 $r$ に応じた拡大率で拡大した楕円 の内側のみを 1 ，それ以外を 0 とするマスク画像 $M(x, y)$ を用いた。拡大率は， $r \leq 5$ 画素で1.7, 5 画 素 $<r \leq 10$ 画素で1.4，10画素＜rで1.2とした。

\subsubsection{2 值化法}

式(10)の 2 值化のしきい值 $P_{\mathrm{T}}$ の值によって計測精度 が異なる可能性が予想されるため, 今回の実験では, $P_{\mathrm{T}}$ として以下の 3 種類の值を設定し, その計測結果を 比較した。

(1) 中間值: $P_{\mathrm{T}}=\left(P_{\mathrm{F}}+P_{\mathrm{B}}\right) / 2=128$

(2) 上側四分值 : $P_{\mathrm{T}}=\left(P_{\mathrm{F}}+3 P_{\mathrm{B}}\right) / 4=160$

(3) 下側四分值: $P_{\mathrm{T}}=\left(3 P_{\mathrm{F}}+P_{\mathrm{B}}\right) / 4=96$

なお, 実験結果において, 特に $P_{\mathrm{T}}$ の值を示していな い場合は， $P_{\mathrm{T}}=128$ (中間值) の結果である。

\subsection{2 加重平均法}

式(11)のしきい值 $P_{\mathrm{L}}$ の值によって計測精度が異なる 可能性が予想されるため, 今回の実験では, $P_{\mathrm{L}}$ として 以下の 5 種類の值を用い, その計測結果を比較した。

(1) 背景值 $-4: P_{\mathrm{L}}=P_{\mathrm{B}}-4=188$

(2) 背景值 $-2: P_{\mathrm{L}}=P_{\mathrm{B}}-2=190$

(3) 背景值 $\pm 0: P_{\mathrm{L}}=P_{\mathrm{B}}=192$

(4) 背景値 $+2: P_{\mathrm{L}}=P_{\mathrm{B}}+2=194$

(5) 背景値 $+4: P_{\mathrm{L}}=P_{\mathrm{B}}+4=196$

なお, 実験結果において, 特に $P_{\mathrm{L}}$ の值を示していな い場合は， $P_{\mathrm{L}}=192$ （背景值 \pm 0 ）の結果である。

\section{2 .3 最小 2 乗マッチング法}

今回の実験では, 幾何変換はアフィン変換とした。 テンプレート画像を円形とし, 3.3で述べた簡易的な方 法で求められた楕円の方程式から変換係数の初期値を 設定すると，回転に関する不定性のため，安定した解
が得られなかった場合が多かった。このため, 求めら れた方程式に対応する楕円を, $4.1 て ゙$ 述べた方法でディ ジタル化した画像をテンプレート画像として, マッチ ングを行った。なお，繰り返し計算の途中で求められ る中心位置が, 初期位置より $x$ 座標あるいは $y$ 座標で 2 画素以上離れた場合は, マッチングに失敗したと判 定した。

\subsection{4 拡大画像を使用した 2 值化法}

以下に示す実験結果で， 2 值化法が加重平均法や最 小 2 乗マッチング法より著しく低い計測精度を示した こと, 半径が大きくなるに従ってその計測精度が向上 したこと，そして画像に含まれる雑音に対してロバス トであったことなどを考慮して，線形内挿法によって 画像を拡大し，その画像に対して 2 值化法を適用する 方法も比較対象に加えた。今回の実験では, 横 2 倍 $\times$ 縦 2 倍あるいは横 4 倍×縦 4 倍に拡大した拡大画像を 使用し, 式(10)の 2 值化のしきい值 $P_{\mathrm{T}}$ は中間值 $\left(P_{\mathrm{T}}=\right.$ 128) とした。以後, 横 $n$ 倍 $\times$ 縦 $n$ 倍に拡大した画像を 使用する方法を $n$ 倍拡大 2 值化法と呼ぶことにする。

なお，実験結果において，特に $n$ の值を示していな い場合は, $n=4$ ( 4 倍拡大 2 值化法) の結果である。

\section{3 計測結果の評価}

1 組の長半径 $a$, 扁平率 $f$, 長軸の回転角 $\alpha$ のター ゲットについて，その中心位置に依存した計測となる のを避けるため, 一様乱数に従って中心位置が画素内 でランダムになるように配置して, 1,024枚のターゲッ 卜画像を作成し，その中心位置を計測した。平均的に は, 横 1 /32画素×縦 1 /32画素間隔で, 楕円の中心位 置が計測されることになる。

ターゲットの中心位置の計測精度の評価は, この 1,024点の計測誤差の RMS で行った。以降, この計測 誤差の RMS を，単に計測誤差と呼ぶことにする。

\section{5. 実験結果と考察}

\section{1 形状の違いによる計測精度の違い}

楕円の形状の違いによる中心位置の計測精度の違い を調べるため, 扁平率 $f$ として 0.0 (円), 0.2，0.4, $0.6,0.8 の 5$ 種類, 長軸の回転角 $\alpha$ として $0^{\circ}, 15^{\circ}, 30^{\circ}$, $45^{\circ}$ の 4 種類について実験を行った, $(f, \alpha)$ の組み合わ せは表 2 に示すような 17 種類となる。 
表 2 扁平率と長軸の回転角の組み合わせ

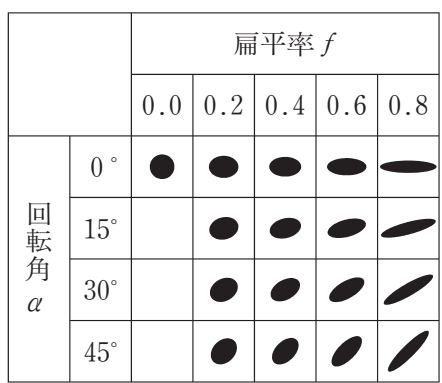

本研究では，楕円の中心位置の計測は 2 次元的処理 であり，その計測精度は楕円の面積に依存すると考之， 扁平率の異なる楕円についての計測精度の比較は，等 面積の楕円について行うことにした。そして，等積円 の半径 $r$ とし， 5 画素，10画素，20画素，40画素の 楕円に対して実験を行った。 2 值化法と拡大 2 值化法 は $P_{\mathrm{T}}=128$, 加重平均法は $P_{\mathrm{L}}=192$ とした。なお, 実験 に用いた画像には雑音を付加していない $\left(\sigma_{\mathrm{N}}=0\right)$ 。実

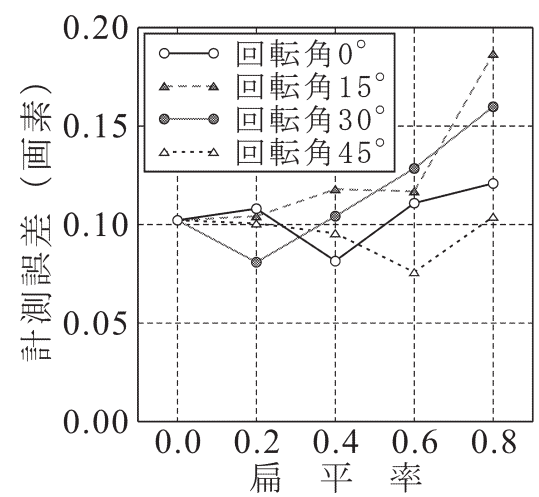

(a) 2 值化法

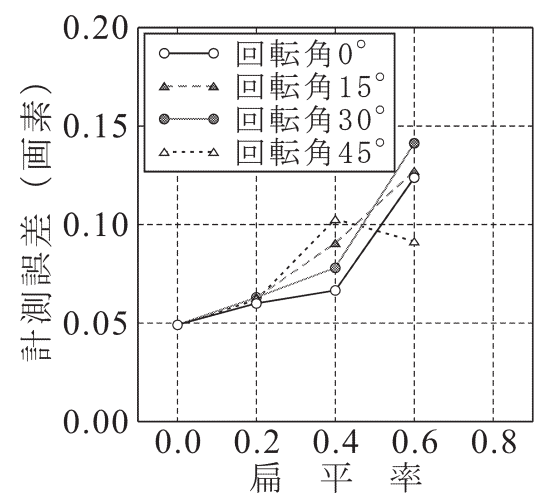

(c) 最小 2 乗マッチング法
験結果を図 4 ～困 7 に示す。また，最小 2 乗マッチン グ法では, 表 3 に示すように，どの大きさの楕円でも， $f=0.8$ でのマッチング失敗率が高かったため, グラフ には $f=0.8$ の結果は含めていない。な扔, 表 3 に示し ていない扁平率に対しては, マッチング失敗は発生し なかった。これらの図表より，以下のことがわかった。

（1）どの計測手法においても，計測精度が楕円の軸の 回転角に依存することを特に示す結果は得られな かった。

（2）どの計測手法においても，扁平率が大きくなるに 従って概ね計測精度が低下した。また， $f=0.2$ の計 測精度は若干のばらつきはあるが, $f=0.0$ (円）の 計測精度とほぼ同程度であると言える結果であっ た。

（3） 2 值化法, 加重平均法, 拡大 2 值化法の計測精度 は，ほぼ同じ傾向を示し，軸の回転角の違いによる ばらつきはあるが, $f=0.6$ でも $f=0.0$ より大きく 計測精度が低下する結果ではなかった。特に, 加重

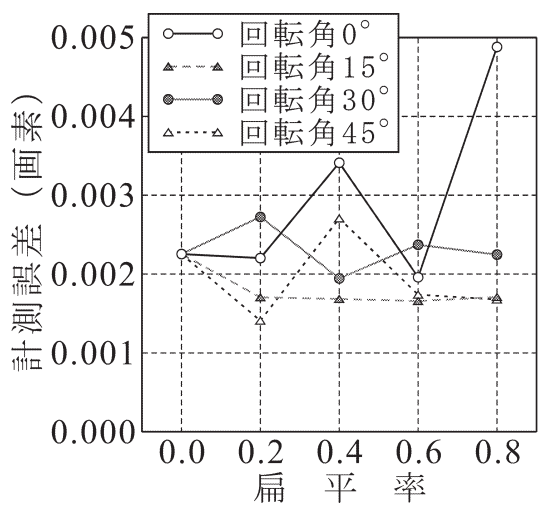

(b) 加重平均法

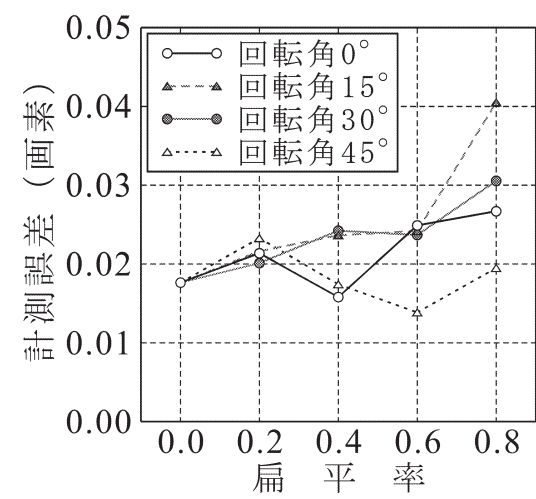

(d) 拡大 2 值化法

図 4 楕円の形状による計測精度の違い $\left(r=5\right.$ 画素, $\left.\sigma_{\mathrm{N}}=0\right)$ 


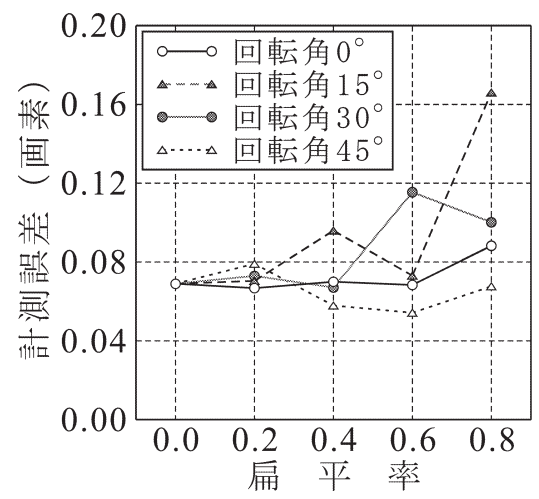

(a) 2 值化法

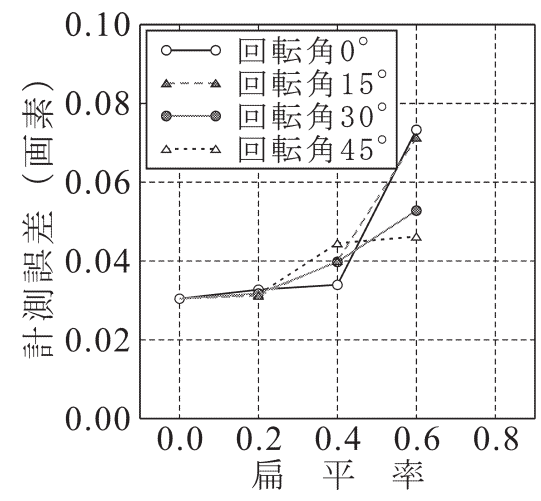

(c) 最小 2 乗マッチング法

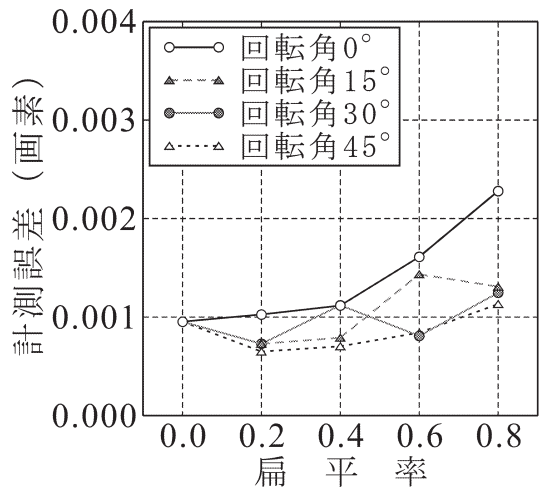

(b) 加重平均法

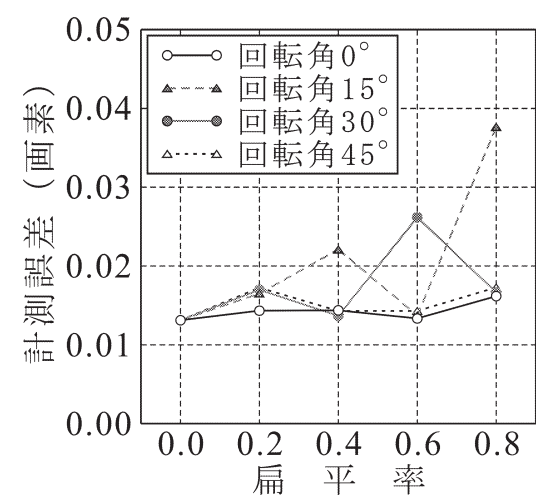

(d) 拡大 2 值化法

図 5 楕円の形状による計測精度の違い $\left(\boldsymbol{r}=10\right.$ 画素, $\left.\sigma_{\mathrm{N}}=0\right)$

平均法は, $r=5$ 画素を除き, $f=0.6$ でも $f=0.0$ と ほぼ同程度と言える計測精度であった。そして,こ れらの手法の $f=0.8$ での計測誤差は $f=0.0$ の計 測誤差の概ね 2 倍以下であった。

（4）最小 2 乗マッチング法の計測精度は, 扁平率に依 存する傾向が最も高く, 特に $f=0.6$ では計測精度 が著しく低下した。また， $f=0.8$ では, 軸の回転角 によっては，マッチングに失敗する率が $50 \%$ を超え る場合があるなど，この手法を偏平した楕円に適用 することが難しいことを示す結果であった。

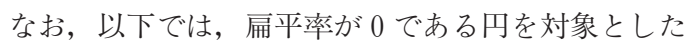
実験結果についてのみ示すことにする。

\section{2 大きさの違いによる計測精度の違い}

画像上のターゲットの大きさの違いによる中心位置 の計測精度の違いを調べるため, 円の半径 $r$ を 2 画素 から40画素まで 0.1 画素ずつ変えて作成した, 雑音が付 加されていない $\left(\sigma_{\mathrm{N}}=0\right)$ 画像を用いて実験を行った。
2 值化法と拡大 2 值化法では $P_{\mathrm{T}}=128$, 加重平均法で は $P_{\mathrm{L}}=192$ とした。この実験結果を図 8 に示す。この 図 8 より，以下のことがわかった。

（1）計測精度が高い順に並べると，すべての半径にお いて, 加重平均法, 拡大 2 值化法, 最小 2 乗マッチ ング法， 2 值化法となった。計測誤差の最大值は, 2 值化法では, $r=2.1$ 画素のときに0.176画素, 加重 平均法では, $r=2.4$ 画素のときに0.009画素, 最小 2 乗マッチング法では, $r=2.3$ 画素のときに0.126画 素, 拡大 2 值化法では, $r=2.1$ 画素のときに0.040画 素であった。

（2） 2 值化法，加重平均法，拡大 2 值化法では，計測 精度が半径に依存して周期的に変動した。その振幅 は, 最も計測精度が低い 2 值化法で最も大きく, 逆 に最も計測精度が高い加重平均法で最も小さくなっ た。また, その周期は 0.5 画素と短く, また単振動に 近い波形であった。これらの計測手法では, 半径が 大きくなるに従って計測誤差の振動の振幅は小さく 


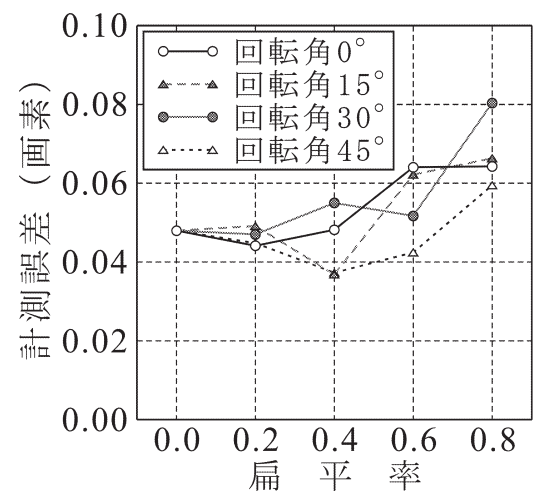

(a) 2 值化法

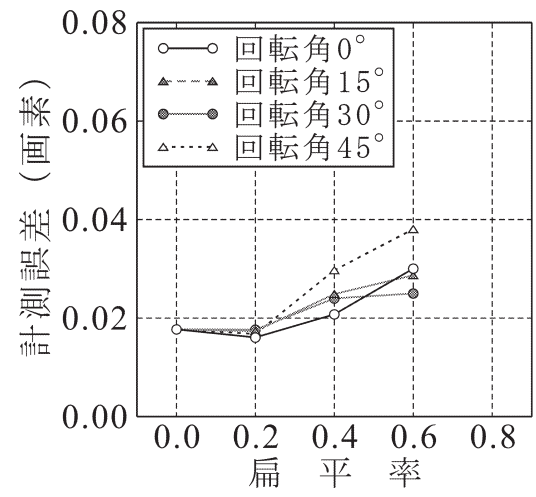

(c) 最小 2 乗マッチング法

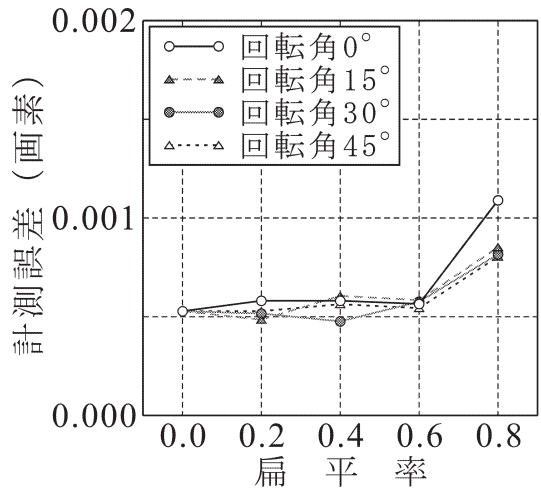

(b) 加重平均法

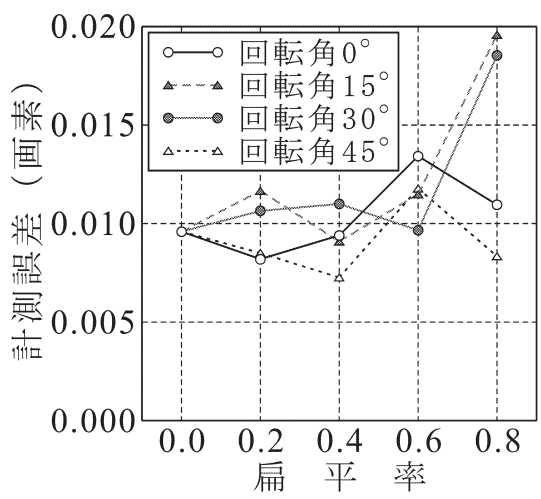

(d) 拡大 2 值化法

図 6 楕円の形状による計測精度の違い $\left(\boldsymbol{r}=20\right.$ 画素, $\left.\sigma_{\mathrm{N}}=0\right)$

なったが, 振動の周期は半径に応じて変化すること はなかった。

（3）最小 2 乗マッチング法でも，半径に従って計測精 度が変動したが, その波形は複雑な形状を示し, 周 期を算定することは困難であった。

計測精度が半径によって周期的に変動することをさ らに詳しく調べるため, 半径 $r$ が, $4 \sim 6$ 画素, $9 \sim 11$ 画素, 19 21画素, 39〜41画素の 4 区間について, 0.05 画素ごとに計測を行った。図 9 に, 中間值 $\left(P_{\mathrm{T}}=128\right)$ による 2 值化法, 上側四分值 $\left(P_{\mathrm{T}}=160\right)$ による 2 值化 法, 加重平均法, 最小 2 乗マッチング法, 拡大 2 值化 法の計測誤差を示す。この図 9 より, 以下のことがわ かった。

（1）すべての区間において，中間值による 2 值化法と 上側四分值による 2 值化法では, 振動の位相が反転 していた。図 9 には示していないが, 下側四分值 $\left(P_{\mathrm{T}}\right.$ =96）による 2 值化法の結果は上側四分值による 2 值化法の結果とほぼ一致するものであった。
（2） 2 值化法では，振動の振幅が大きいため，しきい 值 $P_{\mathrm{T}}$ の設定次第で計測精度が大きく異なることに なる。 $P_{\mathrm{T}}$ の設定值の違いによる 1 周期内での計測誤 差の違いは, 最大で 2 倍程度となっており, 半径に よっては, 中間值を用いた場合が最も計測精度が高 い場合もあれば，上側四分值あるいは下側四分值を 用いた場合が最も計測精度が高い場合もある。

(3) 加重平均法では, 半径が小さい $(r=4 \sim 6$ 画素) ときには, 計測誤差の周期性が明膫に認められるが, 全般的に計測精度が非常に高いため, 特に問題はな いと考えられる。

ここで， 2 值化法による 1 次元の線分の中点の位置 の計測誤差について考えてみる。図形と背景の濃淡レ ベルの中間值をしきい值とした 2 值化法によって線分 の中点の位置を計測したときの誤差の RMS，すなわ ち計測誤差は, 標本化のみを行い, 量子化は行ってい ないディジタル画像に対しては解析的に求めることが でき, 次式(13)に示すように, 線分の長さ $l$ の小数部分 


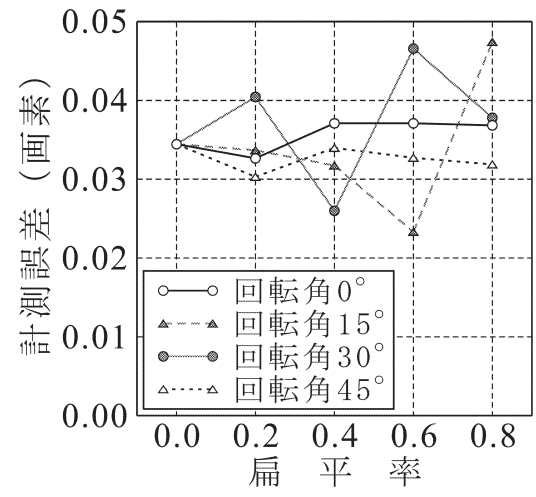

(a) 2 值化法

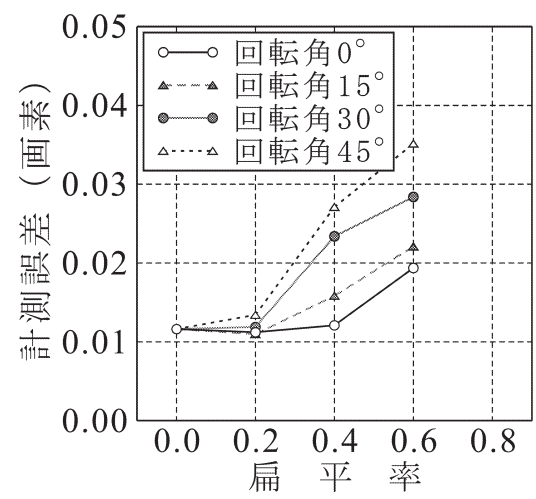

(c) 最小 2 乗マッチング法

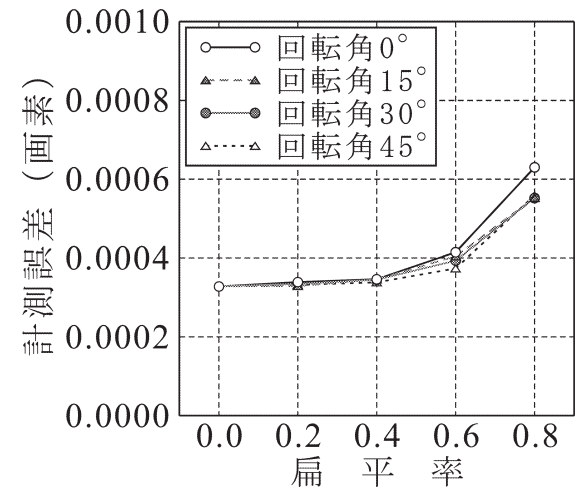

(b) 加重平均法

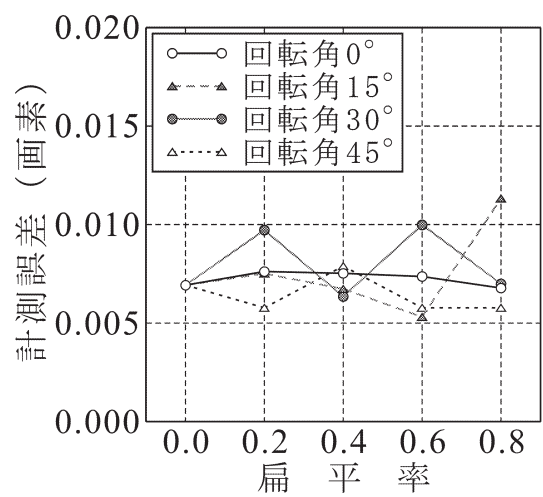

(d) 拡大 2 值化法

図 7 楕円の形状による計測精度の違い $\left(r=40\right.$ 画素, $\left.\sigma_{\mathrm{N}}=0\right)$

表 3 最小 2 乗マッチング法におけるマッチング失敗率

\begin{tabular}{|c|c|c|c|c|c|}
\hline \multirow{2}{*}{$\begin{array}{c}\text { 等積円の半径 } \\
r\end{array}$} & $\begin{array}{c}\text { 扁平率 } \\
f\end{array}$ & \multicolumn{4}{|c|}{ 回転角 $\alpha$} \\
\cline { 3 - 6 } & 0.8 & $39.4 \%$ & $69.4 \%$ & $77.1 \%$ & $23.4 \%$ \\
\hline \multirow{2}{*}{ 5.0画素 } & 0.6 & $0.5 \%$ & $18.7 \%$ & $0.7 \%$ & $0.0 \%$ \\
\hline \multirow{2}{*}{ 10.0画素 } & 0.8 & $37.2 \%$ & $61.3 \%$ & $71.1 \%$ & $47.5 \%$ \\
\cline { 2 - 6 } & 0.8 & $4.8 \%$ & $51.6 \%$ & $58.4 \%$ & $34.1 \%$ \\
\hline 20.0画素 & 0.8 & $10.4 \%$ & $25.4 \%$ & $49.3 \%$ & $55.9 \%$ \\
\hline 40.0画素 & 0.8 & & & \\
\hline
\end{tabular}

$\tau=l-[l]$ ([ ] はガウス記号) の関数となる。この計測 䛊差を $\tau(0 \leq \tau<1)$ について示したのが図10である。 計測誤差 $=\sqrt{\frac{1}{4} \tau^{2}-\frac{1}{4} \tau+\frac{1}{12}}$

このように， 2 值化法による 1 次元の線分の中点の 位置の計測では，しきい值による判定に関係する画素 が線分の両端の 2 画素に限定されるため, 計測䛊差は 長さ $l$ の整数部分 $[l]$ に依存せず, 周期 1 画素で振動

\section{することになる。}

これに対し， 2 次元の円の中心位置を 2 值化法, 加 重平均法, 拡大 2 值化法によって計測するときの誤差 を解析的に求めることは困難であるため, その計測誤 差が, 図 8 や図 9 に示したように周期0.5画素で振動 し，半径が大きくなるに従って小さくなった理由は明 らかではない。

しかし， 2 值化法については, 1 次元の線分の中点 


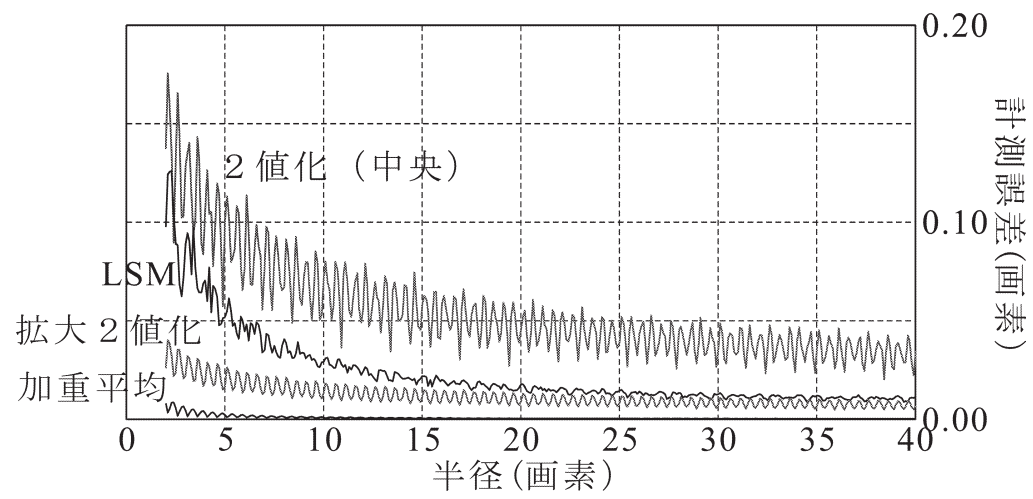

図 8 半径の違いによる中心位置の計測精度の違い $\left(\sigma_{\mathrm{N}}=0\right)$

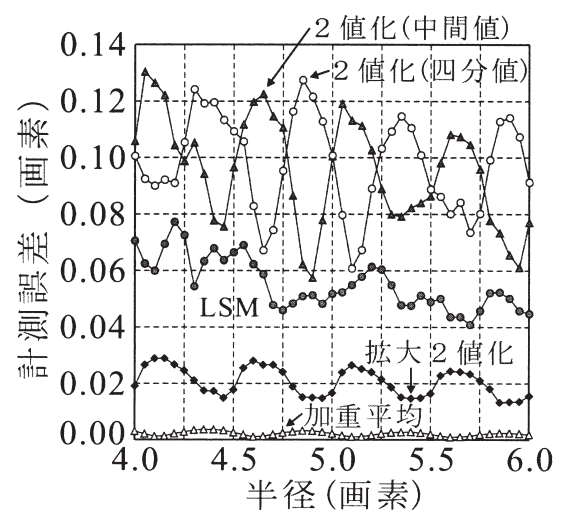

(a) 半径: $4 \sim 6$ 画素

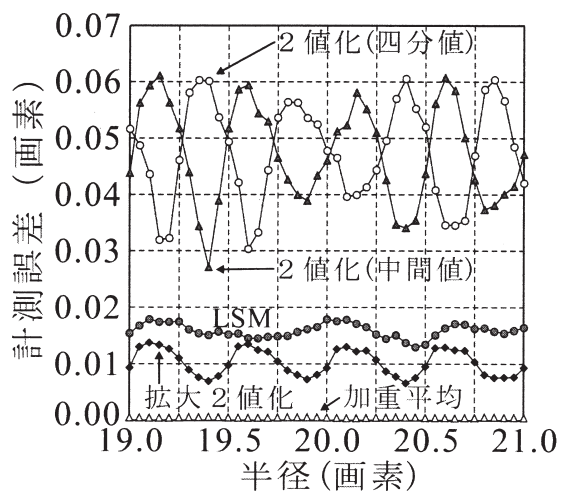

(c) 半径 : 19 21画素

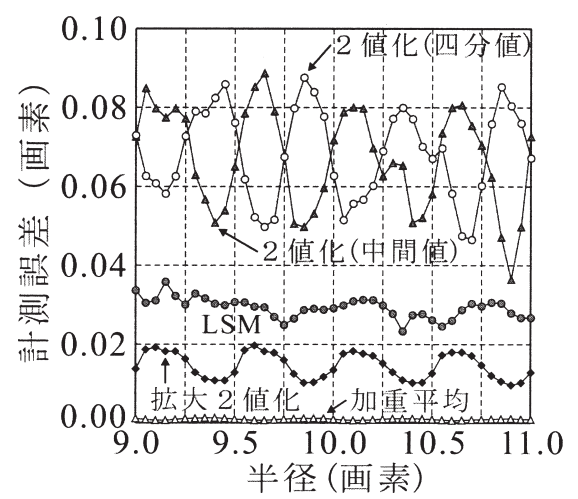

(b) 半径: $9 \sim 11$ 画素

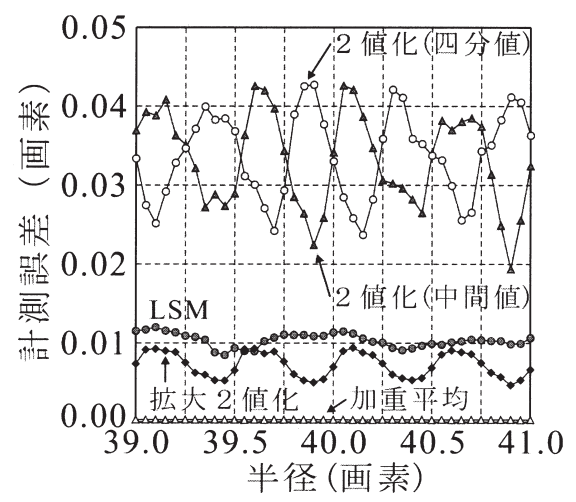

(d) 半径 : 39 41画素

$\leadsto 2$ 值化法（しきい值 : 中間值）

$\multimap 2$ 值化法 (しきい值 : 上四分值)

$\Delta \Delta$ 加重平均法

○最小 2 乗マッチング法 [LSM]

. 4 倍拡大 2 值化法

図 9 計測精度の半径による周期的な変動 $\left(\sigma_{\mathrm{N}}=0\right)$ 


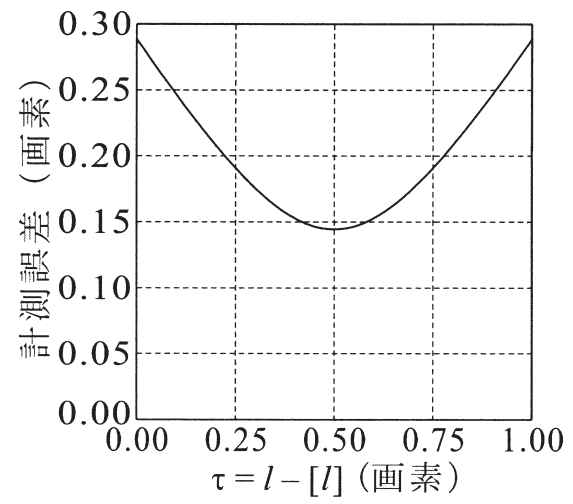

図10 2 值化法による長さ $l$ の線分の中点の計測誤差

の位置の計測誤差が周期 1 画素で振動するということ を 2 次元に拡張して考えると， 2 次元の円の中心の位 置の計測誤差が直径 1 画素 (半径0.5画素) の周期性を 有することは理解できないことではない。

ただし， 1 次元の線分の中点の位置の計測とは異な ク，2 次元の円の中心の位置の計測では，しきい值に よる判定に関係する画素が円の周上の画素となり，そ の画素の数は円の半径 $r$ に比例する。このため, 図 8 に示した 2 值化法による円の中心位置の計測誤差は, $r$ の小数部分 $\tau=r-[r]$ に依存して振動する成分と $\sqrt{r}$ に反比例して減少する成分が合成されたものと考 えられる。

つぎに，計測誤差の周期性の影響を取り除いて，半 径の違いによる中心位置の計測精度の違いを調べるた めに, 半径 $r の \pm 1$ 画素の区間で移動平均をとった結 果を, 図 8 に太線で描き加えた図を図11として示す。 この図11より，以下のことがわかった。

（1）図11には周期性の影響がまだ残ってはいるが，す べての計測手法において, 半径 $r$ が大くなるに
従ってその計測誤差が小さくなった。なお， 2 值化 法と拡大 2 值化法では, ほぼ $\sqrt{r} に 反$ 比例して減少 したが, これに対し, 加重平均法と最小 2 乗マッチ ング法では， $\sqrt{r} に 反$ 比例した減少ではなかった。

(2) 2 值化法では, 移動平均の上下に大きく振動し, 1 周期 0.5 画素中の計測誤差の最大值と最小值の比 は約 2 となった。つまり，1 周期 0.5 画素中の計測誤 差の最大值と最小值は, それぞれ移動平均值の約 $4 /$ 3 倍, 約 $2 / 3$ 倍となった。

（3）拡大 2 值化法でも， 2 值化法より振動の振幅は小 さいが, 同様に移動平均の上下に振動し， 1 周期 0.5 画素中の計測誤差の最大值と最小値の比は約 2 と なった。

\section{3 雑音の大きさの違いによる計測精度の違い}

杂隹音の大きさの違いによる中心位置の計測精度の違 いを調べるため, 半径 $r$ が 5 画素, 10画素, 20画素, 40 画素の 4 種類の円について, 付加雑音の標準偏差 $\sigma_{\mathrm{N}}$ を $0 ， 1 ， 2 ， 3 ， 4 ， 5 ， 6 ， 7 ， 8$ として作成し た 9 種類の画像を用いて, 計測実験を行った。図 9 か らわかるように, この設定した半径の值に対する 2 值 化法や拡大 2 值化法の計測誤差は振動のほぼ中央に位 置する。

また, 拡大 2 值化法については, 横 2 倍 $\times$ 縦 2 倍お よび横 4 倍 $\times$ 縦 4 倍に拡大した 2 種類の拡大画像を使 用した場合の計測精度の違いもあわせて調查した。な お， 2 值化法，拡大 2 值化法（2 倍，4 倍）のしきい 值 $P_{\mathrm{T}}$ は中間值 $\left(P_{\mathrm{T}}=128\right)$ とした。

さらに, 加重平均法のしきい值 $P_{\mathrm{L}}$ の違いによる計 測誤差の違いを調べるため, $P_{\mathrm{L}}$ の值を, 背景値一 $4\left(P_{\mathrm{L}}\right.$ $=188)$, 背景値 $-2\left(P_{\mathrm{L}}=190\right)$, 背景值 $+2\left(P_{\mathrm{L}}=194\right)$,

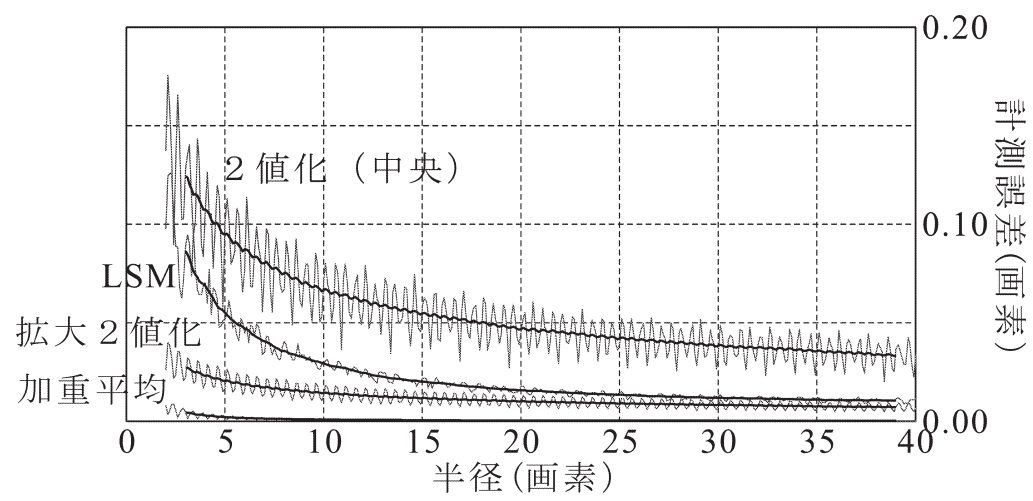

図11 半径の違いによる中心位置の計測精度の違い $\left(\sigma_{\mathrm{N}}=0\right.$, 移動平均あり) 
背景值 $+4 \quad\left(P_{\mathrm{L}}=196\right)$ とした場合の実験も行った。

なお，実験結果を示す罒12および困13では，2 值化 法, 背景值土 0 による加重平均法, 最小 2 乗マッチン グ法の計測誤差を基本とし，図12には 2 倍拡大 2 值化 法と 4 倍拡大 2 值化法の計測誤差を, 四13には異なる しきい值 $P_{\mathrm{L}}$ を用いたときの加重平均法の計測䛊差を 合わせて示すことにする。この眓12および図13より， 以下のことがわかった。

(1) 4 種類の半径すべてにおいて，2 值化法の計測誤 差は最も大きかったが，その值は雑音の大きさには 依存せず，ほぼ一定であった。2 值化法は, 雑音に 対してロバストであると言える。
（2） 4 種類の半径すべてにおいて， 2 倍拡大 2 值化法 と 4 倍拡大 2 值化法は 2 值化法より計測精度が高く なった。また， 4 倍拡大 2 值化法が 2 倍拡大 2 值化 法よりも計測精度が高くなった。ただし， 2 值化法 と異なり, 雑音が大きくなるに従って計測誤差がや や大きくなった。

（3）最小 2 乗マッチング法の計測精度は，拡大 2 值化 法と同様に，雑音が大きくなるに従って計測誤差が やや大きくなった。

（4）しきい值を背景值士0 とした場合の加重平均法の 計測誤差は, 雑音の大きさにほぼ比例する結果と なった。これは, 量子化䛊差を考慮しない場合の理

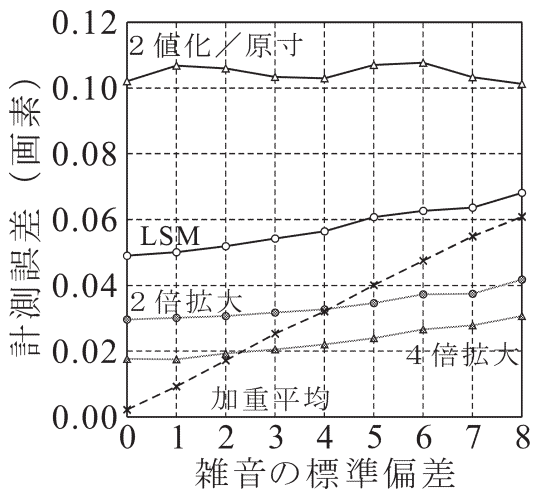

(a) 半径：5画素

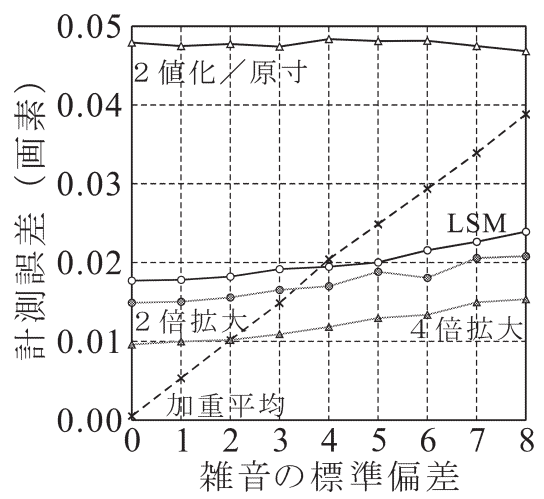

(c) 半径：20画素

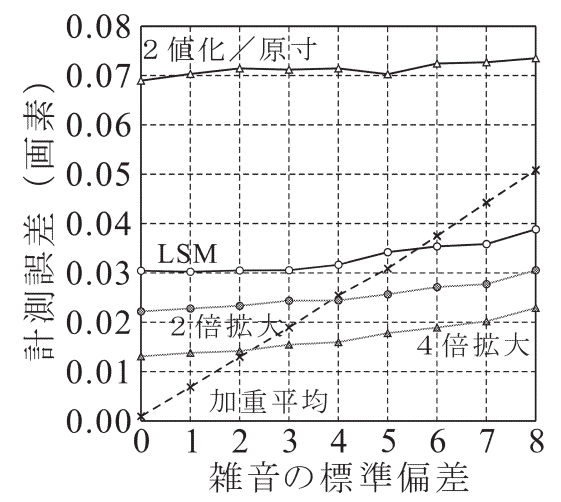

(b) 半径：10画素

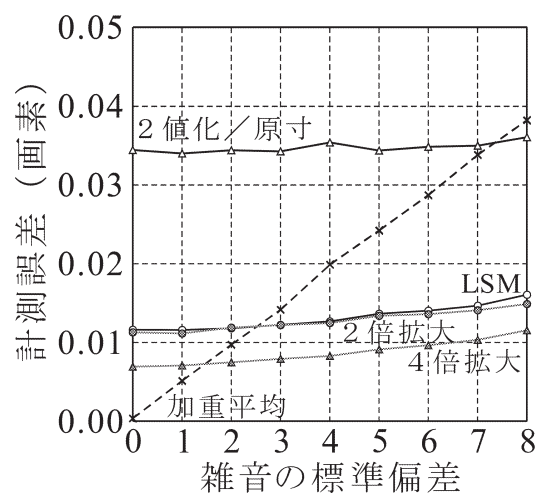

(d) 半径：40画素

$\triangle 2$ 值化法

…2 倍拡大 2 值化法

$\triangle 44$ 倍拡大 2 值化法

*-* 加重平均法

—最小 2 乗マッチング法 [LSM

図12 計測手法による中心位置の計測精度の違い（基本十異なる拡大率の拡大 2 值化法） 


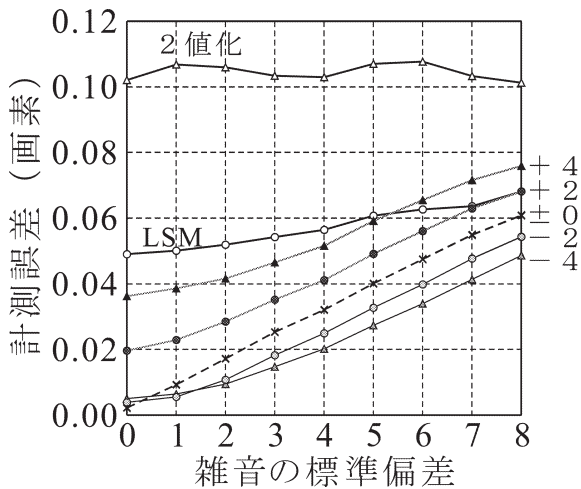

(a) 半径: 5 画素

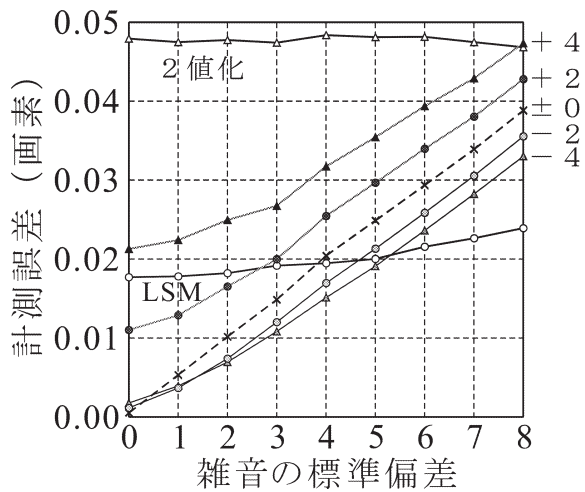

(c) 半径 : 20 画素

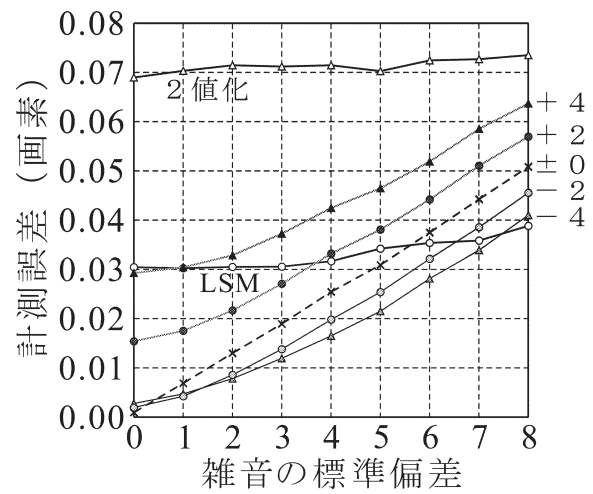

(b) 半径 : 10画素

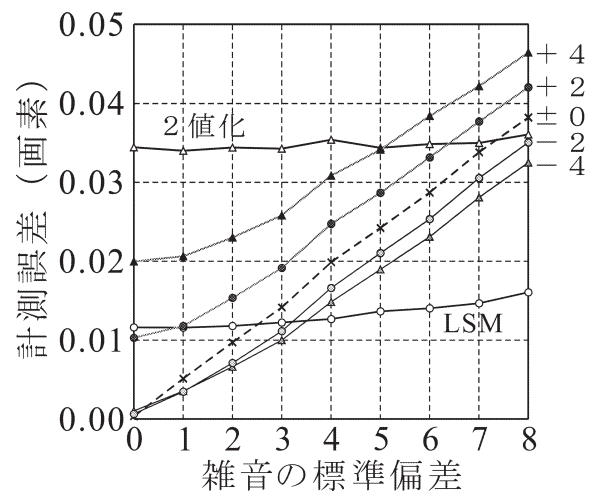

(d) 半径：40画素

$\leadsto 2$ 值化法

、、加重平均法（しきい值：背景值 +4 ）

- ・加重平均法（しきい值：背景值 +2 ）

*-* 加重平均法（しきい值：背景值土 0 )

○。加重平均法（しきい值：背景值一 2 )

$\Delta \Delta$ 加重平均法（しきい值：背景值 -4 )

○最小 2 乗マッチング法 $[\mathrm{LSM}]$

図13計測手法による中心位置の計測精度の違い（基本+異なるしきい值の加重平均法）

論的な計測誤差の性質 (Maas, et al., 1993) と一致 するものである。半径が大きくなるに従って，雑音 による計測精度の低下は著しく, $r=5$ 画素では, $\sigma_{\mathrm{N}}$ $=4$ において，2 倍拡大 2 值化法とほぼ同じ計測精 度であったのに対し， $r=40$ 画素では， $\sigma_{\mathrm{N}}=4$ におい て，拡大 2 值化法（2 倍， 4 倍）や最小 2 乗マッチ ング法より低い計測精度となった。ただし， $r=40$ 画 素の $\sigma_{\mathrm{N}}=8$ を除いて， 2 值化法よりは計測精度が高 かった。

（5）しきい值 $P_{\mathrm{L}}$ を楕円の濃淡レベルに近づけて，背 景值一 2 あるいは背景值 -4 とした場合の計測精度
は，背景值士 0 とした場合の計測精度とほぼ同程度 あるいはやや高い結果であった。これに対し，しき い值 $P_{\mathrm{L}}$ を楕円の濃淡レベルから遠ざけて，背景 值 +2 あるいは背景值十 4 とした場合の計測精度 は，背景值士0とした場合の計測精度より低くなっ た。また，このときの計測誤差は，雑音がないとき $\left(\sigma_{\mathrm{N}}=0\right)$ でも0ではなく,理論值とずれた結果であっ た。このことより，しきい值 $P_{\mathrm{L}}$ を背景の濃淡レベル と等しくするか, あるいはそれよりやや四形の濃淡 レベルに近づけた值に設定することが望ましいと言 える。 


\section{6. 各計測手法の計測精度の特徵}

各計測手法の計測精度の特徵を実験結果に基づいて まとめると, 以下のようになる。ここで, $r$ は円の半径, $f$ は楕円の扁平交, $\sigma_{\mathrm{N}}$ は雑音の標準偏差である。

\subsection{2 值化法}

（1）雑音に対してロバストではあるが， $\sigma_{\mathrm{N}} \leq 8$ での計 測精度は, 他の 3 手法の計測精度より低い。計測対 象が円の場合, $r=2.1$ 画素における計測誤差が 0.18 画素となるなど, 概ね $r \geq 7$ 画素でなければ, 計測䛊 差が0.1画素以下とはならない。

（2）計測対象が円の場合, 計測精度は半径に応じて周 期0.5画素の単振動をする。その振幅は大きく, 1 周 期 0.5 画素中の計測誤差の最大值と最小值の比は約 2 となる。

（3）計測精度は 2 值化のしきい值 $P_{\mathrm{T}}$ に大きく依存す る。計測対象が円の場合, 同じ半径であっても, $P_{\mathrm{T}}$ の值の違いによる計測誤差の最大值と最小值の比は 約 2 となる。

（4）計測精度が楕円の軸の回転角に特に依存すること はない。

（5）楕円の扁平率が大きくなるに従って計測精度は低 下する。ただし， $f \leq 0.6$ の楕円に対しては, 円に対 する計測精度より大きく計測精度が低下することは ない。 $f=0.8$ の楕円に対する計測誤差は円に対する 計測誤差の概ね 2 倍以下となる。

\section{2 加重平均法}

（1）計測誤差は雑音の標準偏差にほぼ比例して大きく なる。計測対象が円の場合, $\sigma_{\mathrm{N}} \leq 2$ では, 他の 3 手法 の計測精度より高くなるが, $\sigma_{\mathrm{N}} \geq 4$ では, $r \geq 10$ 画素 で拡大 2 值化法 ( 2 倍, 4 倍) より, $r \geq 20$ 画素で最 小 2 乗マッチング法や拡大 2 值化法（2 倍，4 倍) より計測精度が低くなる。

（2）計測精度はしきい值 $P_{\mathrm{L}}$ にも依存し， $P_{\mathrm{L}}$ の值を標 準的な背景の濃淡レベルではなく, より図形の濃淡 レベルから遠ざけた值に設定すると, 計測精度は低 下する。

（3） $P_{\mathrm{L}}$ に適切な值を設定し, 雑音が小さいときは, 非 常に高い計測精度が期待できる。

（4）計測精度が楕円の軸の回転角に特に依存すること
はない。

（5）楕円の扁平率が大きくなるに従って計測精度は低 下する。ただし， $f \leq 0.6$ の楕円に対しては, 円に対 する計測精度より大きく計測精度が低下することは ない。 $f=0.8$ の楕円に対する計測䛊差は円に対する 計測誤差の概ね 2 倍以下となる。

\section{3 最小 2 乗マッチング法}

（1）計測精度の雑音に対するロバスト性は 2 值化法と 加重平均法の中間で, 拡大 2 值化法と同程度である。 計測対象が円の場合, $r=5$ 画素のときは, ややロバ ス卜性が低く, $\sigma_{\mathrm{N}} \leq 8$ の計測精度が加重平均法の計 測精度より低くなる。しかし, $r \geq 10$ 画素では, ロバ ス卜性が高く, $r=10$ 画素で $\sigma_{\mathrm{N}} \geq 6, r=20$ 画素で $\sigma_{\mathrm{N}}$ $\geq 4, r=40$ 画素で $\sigma_{\mathrm{N}} \geq 3$ において, 加重平均法の計 測精度を上回る。

（2）計測精度が楕円の軸の回転角に特に依存すること はない。

（3）計測精度は楕円の扁平率に大きく依存する。特に $f=0.6$ の楕円に対しては, 計測精度が著しく低下す る。さらに, $f=0.8$ の楕円に対しては, マッチング に失敗する確率が $50 \%$ を超えることもあり得るな ど，偏平した楕円の計測に適用することは難しい。

\section{4 拡大 2 值化法}

(1) 拡大画像の拡大率が 4 倍以下では，拡大率が大き くなるに従って計測精度は向上する。

（2）計測精度の雑音に対するロバスト性は高く，計測 対象が円の場合, 4 倍拡大 2 值化法の計測精度は, $r=5$ 画素のときは $\sigma_{\mathrm{N}} \geq 3$ で, $r \geq 10$ 画素のときは $\sigma_{\mathrm{N}} \geq 2$ で，加重平均法の計測精度を上回る。

（3）計測対象が円の場合, 計測精度は半径に応じて周 期 0.5 画素の単振動をする。 1 周期 0.5 画素中の計測 誤差の最大值と最小值の比は約 2 となる。

（4）計測精度が楕円の軸の回転角に特に依存すること はない。

（5）楕円の扁平率が大きくなるに従って計測精度は低 下する。ただし， $f \leq 0.6$ の棈円に対しては, 円に対 する計測精度より大きく計測精度が低下することは ない。 $f=0.8$ の楕円に対する計測誤差は円に対する 計測誤差の概ね 2 倍以下となる。 


\section{7.まとめ}

今回の実験結果に基づいてまとめた各計測手法の特 徵は 6 .に示したとおりであるが, 画像に含まれている 雑音の大きさに応じて, 適切な計測手法を選択すれば, 雑音の標準偏差 $\sigma_{\mathrm{N}}$ が 8 以下の画像において, 円あるい は扁平率が 0.4 以下の楕円に対しては, 等積円の半径が 5 画素程度では 0.05 画素，10画素以上では，0.03画素 の計測精度が達成できると考えられる。これに対し， 扁平率が 0.8 程度のかなり偏平した楕円に対する達成 可能な計測精度は, 等積円の半径が 5 画素程度では 0.10画素，10画素以上では，0.05画素程度であると考 えられる。

今回の実験結果より, 円形ターゲットの中心位置を できるだけ高精度に自動的に計測する手法として，以 下の方法が考えられる。

(i) 画像全体あるいは部分画像の濃淡レベルの最大值 と最小值の平均值をしきい值として用いて 2 值化を 行い, 楕円の輪郭画素を抽出し, 楕円の方程式を求 める (3.3参照)。

(ii) 求められた楕円の方程式を用いて, 楕円に確実に 含まれる画素（図形と確実に認められる画素）と栯 円に確実に含まれない画素（背景と確実に認められ る画素）を抽出し，図形と背景の濃淡レベルの平均 值と標準偏差を求める。

(iii) 求められた図形および背景の濃淡レベルの標準偏 差を雑音の標準偏差と考え，この值および図形の形 状に応じて，以下の(iv)あるいは(v)の処理を行う。

(iv) 等積円の半径が約20画素以下の小さな図形では, 雑音の標準偏差が 2 以下のときは, 加重平均法で, 2 以上のときは， 4 倍拡大 2 值化法で中心位置を計 測する。

(v) 等積円の半径が約20画素以上の大きな図形では, 雑音の標準偏差が1.5以下のときは, 加重平均法で。 1.5 以上のときは, 4 倍拡大 2 值化法で中心位置を計 測する。

(受付日2008.9.4，受理日2009.5.12)

\section{参考文献}

クラボウ エレクトロニクス事業部, 2001. Kuraves V. 2.0 .0 オペレーションマニュアルカメラレンズ歪 み補正編。

坂上勝彦, 高木幹雄, 1983 . 反復演算による重なり合っ た粒子像の分離, 情報処理学会論文誌, vol. 24, no. 5, pp.561-567.

近津博文, 国井洋一, 中田隆司, 2001. デジタル写真 測量からみた 300 万デジタルスチルカメラの精度検 証, 写真測量とリモートセンシング, vol. 40, no. 2, pp.33-38.

服部 進, 秋本圭一, 岡本 厚, 長谷川博幸, 井本治 孝, 1999. ターゲット場の多重撮影による基準点の ないCCD カメラキャリブレーション, 電子情報通 信学会論文誌 D-II, vol. J82-D-II, no. 9, pp.13911400 .

服部 進, 秋本圭一, 井本治孝, 2001. コード付きター ゲットを使った工業画像計測の自動化, 電子情報通 信学会論文誌 D-II, vol. J84-D-II, no. 9, pp.20112019 .

EOS Systems Inc., 2003. PhotoModeler Pro 5 User Manual.

Luhmann, T., 1986. “Automatic Point Determination in a Réseau Scanning System," Proceedings, International Society for Photogrammetry and Remote Sensing Commission 5, InterCongress Symposium, Ottawa, Canada, pp.400-408.

Maas, H.-G., Gruen, A., Papantoniou, D.A., 1993. "Particle Tracking in three dimensional flows Part I : Photogrammetric determination of particle coordinates," Experiments in Fluids, vol. 15, pp.133-146.

Zhou, G. 1986. “Accurate Determination of Ellipse Centers in Digital Imagery," Technical Papers of ACSM-ASPRS Annual Convention, Washington D.C., U.S.A., vol. 4, pp.256-264. 